\title{
IMPROVEMENT OF SANDY SOIL CHARACTERISTICS AND ITS PRODUCTIVITY OF WHEAT CROP USING ORGANIC AND MINERAL-N FERTILIZATION
}

\author{
Seham Y. M. Abo-Steet \\ Soils, Water and Environment Res. Inst., Agric. Res. Center, Giza, Egypt \\ Received: Dec. 11, 2018 \\ Accepted: Dec. 30,2018
}

\begin{abstract}
A field experiment was carried out on sandy soil at the Farm of Ismailia Agric. Res. Station, Ismailia Governorate, Egypt (Latitude, $30^{\circ} 35^{\prime} 41.901 " N$ and longitude, 32 $2^{\circ} 16^{\prime} 45.834^{\prime \prime}$ E) during the two successive growing winter seasons, i.e., 2016 / 2017 and 2017 / 2018 on wheat plant (Triticum aestivum L.) variety Misr 1, to study the individual and combined effect of organic fertilizers (farmyard manure or potassium humate) and mineral nitrogen fertilization levels $\left(0,50,75\right.$ and $100 \mathrm{~kg} \mathrm{~N} \mathrm{fed}^{-1}$ as ammonium nitrate "33.5 \% N") on plant growth, yield and its components as well as nutrient contents, apparent nitrogen recovery efficiency (ANRE) and agronomical efficiency, also on some chemical and physical properties of the studied soil. Application rates of farmyard manure (FYM) were 0 and 5 ton fed. ${ }^{-1}$, while potassium humate at rates of 0 and $5 \mathrm{~kg} \mathrm{fed}^{-1}$. The layout of the experiment was a split- plot design, with the main plots arranged in a randomized complete blocks design, with three replicates.
\end{abstract}

The results showed that, there are a significant increases of the estimated growth parameters, i.e. plant height (cm), spike length (cm), number of tillers/ plant, number grains/ spike as well as straw and grain yields of wheat plants and their content (concentration and uptake) of the determined macro- ( $N, P$ and $K$ ) and micro- ( $F e, M n$ and $Z n$ ) nutrients and protein content as a result of $N, F Y M$ and $K$-humate applications in both individually and together. The highest values of these determinations were found in the plants fertilized by $N+F Y M$ followed by these resulted from the treatment of $N+$ potassium humate, except weight 1000 grains, grain yield and $K$ content which gave the highest values with the treatment of $N+$ potassium humate. In addition, individual applications of $N$ resulted in a decrease in the soil content of available macro- ( $N, P$ and $K)$ and micro- (Fe, Mn and $\mathrm{Zn}$ ) nutrients, but increased the soil content of available compared with the control treatment. On the other hand, there are an increase of soil content of available macro- and micro-nutrients under study as a result of individual applications of FYM and K-humate with the superior increase of FYM compared with that with $K$-humate, except the soil content of available $K$. Also, the soil content of OM was decreased with the increase of added $N$, but increased as a result of FYM and K-humate applications alone. Soil bulk density was increased in the fertilized by $N$ alone and decreased in the soil fertilized by individual applications of FYM and $K$-humate.

The obtained data from this study concluded that, under sandy soil conditions, organic fertilizers played a major role in sandy soil fertility and its productivity of wheat plants and it's become more efficiency if its application in combination with mineral nitrogen fertilization.

Key words: Sandy soil, Farmyard manure, Potassium humate, Mineral nitrogen fertilizer, Wheat plants, Growth parameters and Chemical composition.

\section{INTRODUCTION}

For the urgent need to meet food and dress demands in Egypt, more desert areas either sandy or calcareous have to be put under cultivation. Such soil are poor with respect to their physic-bio- 
chemical properties, soil water-plant relationships as well as their nutritional status. Sandy soils in Egypt represents more than $70 \%$ of total area. Most of these soils may be reclaimed with low costs compared with other desert soils. Also, these soils are more suitable to many economical cultivations such as wheat, barley and corn. In addition, such soils are located within or near to the Valley of Nile River (FAO, 2011).

Farmyard manure has played an important role in the continuous supply of well-balanced diets of nutrients to crops and represents an important component of the nutrients cycle in agricultural ecosystems. Ali et al. (2005) indicated that $\mathrm{pH}$ and EC values were slightly decreased with FYM application at rate of 2 or $3 \%$ to sandy soil after harvesting maize. Several studies have assured the roles of organic amendments as an improving agent. The improvement of soil physical and chemical properties as well as nutrients status depends to a great extent on the rational use of organic materials as amendments. Seddik (2006) found that N, P and K contents in studied plant parts as well as yield components for both tomato and pea plants generally increased with application of organic manure (FYM and chicken manure) and natural minerals. Farm yard manure also improves the soil $\mathrm{pH}$ of the moderately acidic soils if applied repeatedly over several seasons. It's a good source of $K$ and $N$. Therefore, it is hoped that the use of FYM alone or in combination with fertilizers will gradually improve and sustain soil productivity over the years (Mwangi, 2010).

Potassium humate is an organic fertilizer which effects on plant growth and increase crop yield. Humic acid (HA) particularly is used to remove or decrease the negative effects of mineral fertilizers and some chemicals forms in the soil. So, humic substances have many beneficial effects on soil and consequently on plant growth and are shown highly hormonal activity. These materials not only increase macronutrients contents and ions uptake but also enhance micronutrients of the plant organs (Brunetti et al., 2005 and Kumar et al., 2013). In addition, Montaser et al. (2011) reported that the humic acid (HA) may increase the permeability of plant membranes and enhance the uptake of nutrients. Moreover, HA may also improve soil nitrogen uptake and facilitate the uptake of potassium, calcium, magnesium and phosphorus, making these nutrients more mobile and available to plant root systems. Also, humic substances are organic substances of high molecular weights, and they are naturally widespread in aquatic and terrestrial environments. On the other hand, potassium is one of the essential nutrients required for plant growth and reproduction. In general, potassium plays an important role in many of the vital physiological process in the plant, such as transpiration, translocation of sugars and starch, protein formation and osmotic regulation ( Basak, 2006 ).

Nitrogen is the most important essential nutrient for plant growth. It is a fertilizer in a balance and rational way to keep high and stable yield in important component of proteins, enzymes and vitamins in plant. It is a central part of the chlorophyll and essential photosynthetic molecule. The excessive application of mineral fertilizers led to increase production cost. The residual of mineral fertilizers has seriously affected the quality of agricultural products people's health and caused environmental pollution. Therefore a great interest has been generated to apply bioorganic and inorganic fertilizers to establish a good ecoenvironment ( Basak, 2006 ). Nitrogen fertilizers are economically an expensive input. In many instances less than $60 \%$ 
of the added $\mathrm{N}$ is recovered in the ( crop + soil ) with the remainder being lost by processes such as volatilization, leaching, immobilization and denitrification. Thus, it is necessary to develop fertilizer management practices that can reduce losses and increase the nitrogen use efficiency (Yusron and Phillips, 1997 ).

Wheat plant (Triticum aestivum L.) is considered one of the most important cereal crops in the world. The mass production of wheat in Egypt $(8$ million ton) is about $50 \%$ lower than the consumption (14.5 million ton $I$ year at 2010). Therefore, more than six million tons must be imported annually. One or more of various manners should be followed. The first is by increasing the cultivated area of wheat in both old and newly reclaimed soils. The second is by growing resistant cultivars (plant certified must-free seed) which is considered the most economical and effective way of controlling diseases. The third is by improving agriculture practices among which are the time, irrigation and amount of chemical fertilization (Elbaalawy, 2010).

Therefore, the main targets of the current investigation are improvement of sandy soil characteristics (physical and chemical) and its highest productivity of wheat crop (quantity and quality) using FYM or K-humate individually and combination with mineral- $\mathrm{N}$ fertilization.

\section{MATERIALS AND METHODS}

A field experiment was carried out on sandy soil at the Farm of Ismailia Agric. Res. Station, Ismailia Governorate, Egypt (Latitude, $30^{\circ} 35^{\prime} 41.901 " \mathrm{~N}$ and longitude, $32^{\circ} 16^{\prime} 45.834 "$ E) during the two successive growing winter seasons, i.e., 2016 / 2017 and 2017 | 2018 on wheat plant (Triticum aestivum L.) variety Misr 1 , to study the individual and combined effect of organic fertilizers (farmyard manure or potassium humate) and mineral nitrogen fertilization levels ( 0 , 50,75 and $100 \mathrm{~kg} \mathrm{~N}$ fed. ${ }^{-1}$ as ammonium nitrate "33.5 \% N") on plant growth, yield and its components as well as nutrient contents, apparent nitrogen recovery efficiency (ANRE) and agronomical efficiency, also on some chemical and physical properties of the studied soil. Application rates of farmyard manure (FYM) were 0 and 5 ton fed. ${ }^{-1}$, while potassium humate at rates of 0 and $5 \mathrm{~kg}$ fed. $^{-1}$. The layout of the experiment was a split- plot design, with the main plots arranged in a randomized complete blocks design, with three replicates. The main plots were occupied with the organic fertilizers (farmyard manure or potassium humate) and sub-plots were assigned to mineral nitrogen fertilization levels. All agricultural practices beginning from preparation of soil to sowing until harvesting were carried out as recommended by Egyptian Ministry of Agriculture.

Before sowing, surface soil sample (0 - $30 \mathrm{~cm}$ ) of the experimental soil was taken, air - dried, ground, sieved through a $2 \mathrm{~mm}$ sieve, kept and analyzed for some physical and chemical properties and its content of available macro- (N, P and $K$ ) and micro- (Fe, $M n$ and $\mathrm{Zn}$ ) nutrients according to the methods described by Cottenie et al. (1982); Page et al. (1982) and Kim (1996). The obtained data were recorded in Table (1). Some chemical properties of farmyard manure and K-humate were determined according to methods described by Page et al. (1982) and data are presented in Tables (2 and 3 ).

The FYM and K-humate were applied thoroughly incorporated in the soil before sowing and good mixed with the surface soil of the experimental plots. Before sowing, all plots were fertilized with $100 \mathrm{~kg}$ /fed. of ordinary super phosphate $\left(15.5 \% \mathrm{P}_{2} \mathrm{O}_{5}\right)$, during the final 
soil preparation. Potassium fertilizer 24 $\mathrm{kg} \mathrm{K}_{2} \mathrm{O}$ / fed. was added as potassium sulphate $\left(\begin{array}{llll}48 & \% & K_{2} \mathrm{O}\end{array}\right)$ before the $1^{\text {st }}$ irrigation. Nitrogen fertilizer at different rates were added in three equal doses of 15,30 and 45 days after planting.

Table (1): Some physical, chemical and fertility characteristics of the studied soil.

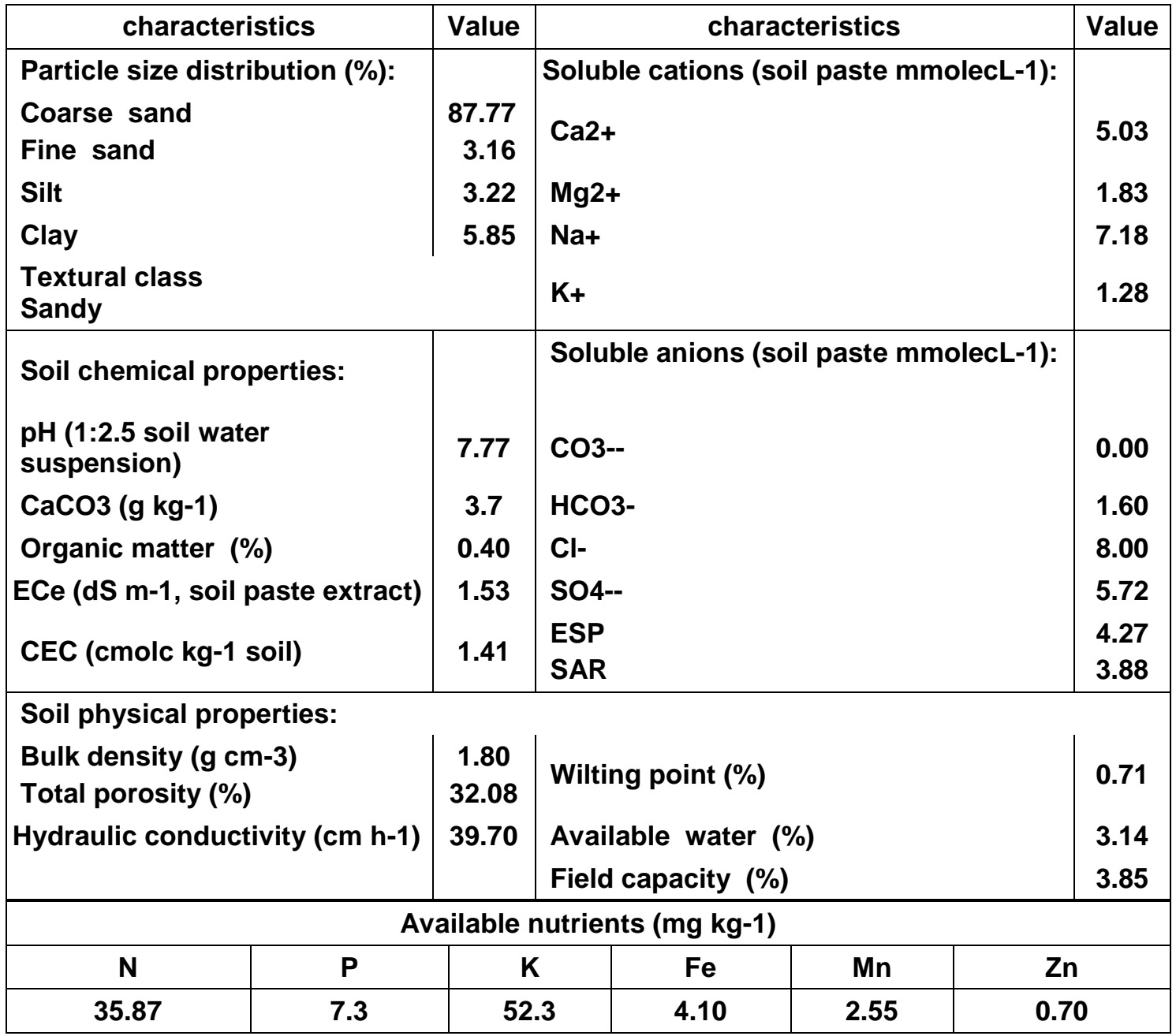

Table (2) : Some composition of farmyard manure (FYM) used.

\begin{tabular}{|c|c|c|c|}
\hline Characteristics & Value & Characteristics & Value \\
\hline Bulk density (g/cm3) & & Macronutrients & \\
Multiuser (\%) & 0.65 & Total N (\%) & 0.90 \\
pH* $^{*}$ & 12.00 & Total P (\%) & 0.65 \\
EC $^{* *}(\mathrm{dS}$ m-1) & 7.23 & Total K (\%) & 0.95 \\
Organic matter (\%) & 2.76 & NH4-N ( mg kg-1) & 36 \\
Organic carbon (\%) & 19.94 & NO3-N ( mg kg-1) & 193 \\
Ash & 11.50 & Micronutrients ( mg kg-1) & \\
C/N ratio & 80.06 & Total Fe & 198 \\
& $13: 1$ & Total Mn & 120 \\
& & Total Zn & 95 \\
\hline
\end{tabular}

*Soil-water suspension 1: $5 \quad$ **Soil water extract 1: 5 
Table (3): Some composition of potassium humate (K-humate) used.

a) Typical analysis.

\begin{tabular}{|c|c|c|c|c|}
\hline Humic acid & Moisture & $\mathrm{pH}(1 \%)$ & $\begin{array}{c}\text { Water } \\
\text { solubility }\end{array}$ & Appearance \\
\hline $70 \%$ & $15 \%$ & $9-10$ & $90 \%$ & Black \\
\hline
\end{tabular}

b) Organic and mineral components.

\begin{tabular}{|c|c|c|c|c|c|}
\hline C & \multicolumn{2}{|c|}{ H } & 0 & $\mathbf{N}$ & $\mathbf{S}$ \\
\hline $50 \%$ & \multicolumn{2}{|c|}{$2 \%$} & $30 \%$ & $.7 \%$ & $0.3 \%$ \\
\hline K2O & P2O5 & $\mathrm{Na}$ & $\mathrm{Ca}$ & Mg & $\mathrm{Fe}$ \\
\hline $12 \%$ & $0.05 \%$ & $0.5 \%$ & $0.5 \%$ & $0.05 \%$ & $1500 \mathrm{mg} / \mathrm{kg}$ \\
\hline $\mathrm{Cu}$ & $\mathrm{Zn}$ & Mn & Si & Mo & B \\
\hline $5 \mathrm{mg} / \mathrm{kg}$ & $15 \mathrm{mg} / \mathrm{kg}$ & $15 \mathrm{mg} / \mathrm{kg}$ & $10 \mathrm{mg} / \mathrm{kg}$ & $0.5 \mathrm{mg} / \mathrm{kg}$ & $200 \mathrm{mg} / \mathrm{kg}$ \\
\hline Al & $\mathrm{Cr}$ & $\mathbf{P b}$ & As & $\mathrm{Hg}$ & Cd \\
\hline $0.1 \%$ & $10 \mathrm{mg} / \mathrm{kg}$ & $15 \mathrm{mg} / \mathrm{kg}$ & $5 \mathrm{mg} / \mathrm{kg}$ & $1 \mathrm{mg} / \mathrm{kg}$ & $1 \mathrm{mg} / \mathrm{kg}$ \\
\hline
\end{tabular}

c) Functional groups components.

\begin{tabular}{|c|c|c|c|c|c|}
\hline Total acidity & $\begin{array}{c}\text { Total } \\
\text { carboxyl }\end{array}$ & $\begin{array}{c}\text { Total } \\
\text { hydroxyl }\end{array}$ & $\begin{array}{c}\text { Total } \\
\text { carbonyl }\end{array}$ & $\begin{array}{l}\text { Phenolic } \\
\text { hydroxyl }\end{array}$ & $\begin{array}{l}\text { Alcoholic } \\
\text { hydroxyl }\end{array}$ \\
\hline $588 \mathrm{cmol} / \mathrm{kg}$ & $382 \mathrm{cmol} / \mathrm{kg}$ & $195 \mathrm{cmol} / \mathrm{kg}$ & $43 \mathrm{cmol} / \mathrm{kg}$ & $126 \mathrm{cmol} / \mathrm{kg}$ & $54 \mathrm{cmol} / \mathrm{kg}$ \\
\hline
\end{tabular}

The present experiment includes 36 experimental units (plots) including 12 treatments $\times 3$ replicates. The area of each plot was $10.5 \mathrm{~m}^{2}$ (3.5 m length $\times 3 \mathrm{~m}$ width; 1/400 fed.). Wheat grains (Misr 1 , cv.) were sown at $21^{\text {st }}$ and $25^{\text {th }}$ November during the first and second season respectively.

Just before harvesting, ten plants were taken randomly from each plot. Some growth parameters, i.e., plant height $(\mathrm{cm})$, spike length $(\mathrm{cm})$, number of tillers/ plant and number of grains/ spike. At harvesting time, the plants of each plot were harvested separately. The grains were separated from straw to measure: weight of 1000 grains (g), grains and straw yield as $\mathbf{k g} / \mathrm{fed}$. and were recorded. Biological yield (kg /fed.), harvest index (\%) of wheat yield (grains) and agronomical efficiency were calculated. Grain and straw samples were air-dried then, oven-dried at $70^{\circ} \mathrm{C}$ for 48 hrs., weighed, ground and digested for chemical determination according to the method described by Chapman and Pratt (1961). Nitrogen, $P$ and $K$ content in the digests were determined according to the methods described by Cottenie et al. (1982). Crude protein percentage was estimated in the different parts by multiplying $N$ \% values by 5.75 as described by A.O.A.C. (1990). The atomic absorption spectrophotometer was used to determine $\mathrm{Fe}, \mathrm{Mn}$ and $\mathrm{Zn}$ concentrations in the prior parts according to the methods recommended by A. O. A. C. (1990). Apparent nitrogen recovery efficiency (ANRE) was calculated according to Quanbao et al. (2007). ANRE $=$ \{ (uptake of $\mathrm{N}$ in treatment fertilized, $\mathrm{kg}$ fed. $^{-1}$ - uptake of $\mathrm{N}$ in control, $\mathbf{k g ~ f e d}^{-1}$ ) /quantity of $\mathrm{N}$ fertilizer applied (kg fed. $\left.\left.{ }^{-1}\right)\right\} \times 100$.

After harvesting, surface soil samples $(0-30 \mathrm{~cm})$ were taken separately from 
each experimental plot and prepared for some physical properties as prementioned. Also, available macro- $(\mathrm{N}$, $P$ and $K$ ) and micro- ( $\mathrm{Fe}, \mathrm{Mn}$ and $\mathrm{Zn}$ ) nutrients according to the methods described by Cottenie et al. (1982); Page et al. (1982) and Kim (1996). The obtained data were recorded in Tables (10 and 11).

The data were exposed to statistical analysis according to Gomez and Gomez (1984). The significant differences among means were tested using the least significant differences (L.S.D.) at $5 \%$ level of significant error.

\section{RESULTS AND DISCUSSION}

\section{Growth Parameters:}

The data presented in Table (4) showed the effect of nitrogen levels on some growth parameters of wheat plants i.e., plant height $(\mathrm{cm})$, spike length $(\mathrm{cm})$, number of tillers/ plant and number of grains/spike. The results revealed that, the maximum values of the previous growth parameters 118.0, 17.9, 3.7 and 50.1 were found in the treatment of $\mathbf{1 0 0}$ $\mathrm{kg} \mathrm{N}$ fed $^{-1}$ and minimum values $86.8,9.3$, 3.0 and 41.3 in the treatment of control, respectively. The relative increase (\%) in the abovementioned parameters were 35.94, 92.47, 23.33 and 21.31, respectively, when compared with the control treatment without $\mathbf{N}$ addition. It could be noticed that all studied growth parameters significantly increased with increasing the nitrogen fertilizer levels. The increase in growth parameters combined with increasing nitrogen fertilization may be attributed to the role of nitrogen in improving the photosynthesis, increasing leaf area, meristematic activity which led to the increase in number of cells and cell elongation, consequently increasing the vegetative growth of wheat plants. These results are in harmony with those recorded by Tantawy et al. (2011); Shah et al. (2013) and Zakaria (2018).

Table (4): Some vegetative growth parameters of wheat plant as affected by the studied treatments.

\begin{tabular}{|c|c|c|c|c|c|}
\hline $\begin{array}{c}\text { Organic } \\
\text { fertilizers }\end{array}$ & $\begin{array}{c}\text { Rate of } \\
\text { mineral N } \\
\text { (kg fed. -1) }\end{array}$ & $\begin{array}{l}\text { Plant height } \\
\text { (cm) }\end{array}$ & $\begin{array}{c}\text { Spike } \\
\text { length }(\mathrm{cm})\end{array}$ & $\begin{array}{l}\text { No. of } \\
\text { tillers/ plant }\end{array}$ & $\begin{array}{c}\text { No. of } \\
\text { grains/spike }\end{array}$ \\
\hline \multirow{4}{*}{ Without } & 0 & 86.8 & 9.3 & 3.0 & 41.3 \\
\hline & 50 & 108.0 & 11.7 & 3.3 & 46.4 \\
\hline & 75 & 115.0 & 14.2 & 3.3 & 47.8 \\
\hline & 100 & 118.0 & 17.9 & 3.7 & 50.1 \\
\hline \multicolumn{2}{|c|}{ Mean } & 106.95 & 13.28 & 3.33 & 46.4 \\
\hline \multirow{4}{*}{$\begin{array}{c}\text { FYM } \\
\text { (ton fed.-1) }\end{array}$} & 0 & 100.2 & 12.3 & 3.7 & 48.7 \\
\hline & 50 & 115.9 & 14.2 & 4.3 & 50.2 \\
\hline & 75 & 120.6 & 17.8 & 4.3 & 51.6 \\
\hline & 100 & 130.4 & 20.8 & 4.7 & 59.0 \\
\hline \multicolumn{2}{|c|}{ Mean } & 116.78 & 16.28 & 4.25 & 52.38 \\
\hline \multirow{4}{*}{$\begin{array}{l}\text { K-humate } \\
\text { (kg fed.-1) }\end{array}$} & 0 & 94.2 & 10.7 & 3.3 & 47.5 \\
\hline & 50 & 112.0 & 12.8 & 3.6 & 48.7 \\
\hline & 75 & 116.4 & 15.6 & 4.0 & 50.6 \\
\hline & 100 & 119.5 & 19.5 & 4.3 & 54.2 \\
\hline \multicolumn{2}{|c|}{ Mean } & 110.53 & 14.65 & 3.83 & 50.25 \\
\hline
\end{tabular}




\begin{tabular}{|c|c|c|c|c|}
\hline L.S.D. at 5 \% & & & & \\
Organic fertilizers: (A) & 0.907 & 0.386 & 0.506 & 0.637 \\
Rate of mineral N: (B) & 1.047 & 0.445 & 0.584 & 0.793 \\
Interaction: (A) x (B) & 1.815 & NS & NS & 1.374 \\
\hline
\end{tabular}

Regarding to the effect of individual applications of either of FYM and Khumate on the four growth parameters of wheat plants presented in Table (4) may be noted that, comparing the data of control treatment (untreated plants), individual applications of FYM and Khumate causeed a significant increases of the estimated growth parameters i.e., plant height $(\mathrm{cm})$, spike length $(\mathrm{cm})$, number of tillers/ plant and number of grains/ spike. The found increases of the plant growth parameters as a result of FYM application alone were higher than those resulted from individual application of K-humate. The increases of these growth parameters as a result of FYM and K-humate may be attributed to their enhanced plant growth and nutrients uptake, in addition their improve effect on physical, chemical and biological soil properties and its content of available macro- and micro- nutrients. In this respect, El-Koumey et al. (2017) and Zakaria (2018) obtained on similar results. The superior increase effect of FYM application alone on the values of the estimated growth parameters compared with those resulted from the individual application of K-humate may be resulted from the greater effect of FYM application on the improve of soil properties and its content of available nutrients compared with these associated with the individual application of K-humate which resulted from the high content of essential plant nutrients in FYM compared with those in K-humate, except $K$ content (Tables, 2 and 3 ).

The combination of organic materials and $\mathbf{N}$ fertilizers showed greater than the above mentioned parameters of plant growth than their sole application (Table,
4). The means regarding, i.e., plant height (cm), spike length (cm), number of tillers/ plant and number of grainsl spike, revealed that the highest values were 130.4, 20.8, 4.8 and 59.0 for plant height (cm), spike length $(\mathrm{cm})$, number of tillers/ plant and number of grainsl spike, respectively which obtained with application of 5 ton FYM fed. ${ }^{-1}$ combined with $100 \mathrm{~kg} \mathrm{~N}$ fed. ${ }^{-1}$, while the values of the same growth parameters 119.5, 19.5, 4.2 and 54.2, respectively which observed with the treatment of 5 kg fed. ${ }^{-1}$ potassium humate in the presence of 100 $\mathrm{kg} \mathrm{N}$ fed. $^{-1}$. Humic substances have a very strong affected on the growth of wheat roots. When humic and fulvic acids and other humic substances added to the soil, enhancement of root initiation and increased root growth may be observed (Mikkelsen, 2005 and Abd ElAal, 2018). Jones et al. (2007); Singh et al. (2013) and Zakaria (2018) concluded that application of humic acid and other organic manures (compost, FYM, humates......etc) improved growth parameters and promotes photosynthesis and transport assimilates of the carbohydrates to the storage organs of wheat and maize plants.

\section{Yield and Its Components:}

Data attained in Table (5) represent the values of wheat 1000-grain weight (g), grains, straw and biological yield ( $k g$ fed. $^{-1}$ ) as well as harvest index (\%) and agronomical efficiency as effected by individual or combined treatments of $\mathrm{N}$ and organic fertilizers. These data reveals that, increasing rates of added mineral $\mathbf{N}$ fertilizers resulted in $\mathbf{a}$ significant increase of dry weight of both 1000-grain, grains, straw and biological yield. The relative increases over control, reached to $48.75,208.33,236.96$ and 
$227.14 \%$ for each 1000-grain weight, grains, straw and biological yield, respectively. These increases may be due to the nitrogen is one of the most important components of cytoplasm, nucleic acids and chlorophyll, so nitrogen has an important role in encouraging cell elongation, cell division and consequently increasing vegetative growth and activation of photosynthesis process which enhance the amount of the metabolites necessary for building plant organs which reflect increases in grain and straw yields. These increases were resulted from the enhanced effect of $\mathbf{N}$ fertilization on plant growth which early recorded from many studies ( Basak, 2006; Tantawy et al., 2011 and Abd ElKader, 2016).

In addition, the data in Table (5) showed that, the individual applications of either of FYM or K-humate were associated with an significant increases of 1000-grain weight (g), grains, straw and biological yield ( $\mathrm{kg} \mathrm{fed}^{-1}$ ) of wheat plants. The highest values of wheat 1000 grain weight (g) and grains yield (kg fed..$^{-1}$ ) were a resulted in K-humate application, while the highest yield of straw and biological yield were a resulted in FYM, under the same application rate of mineral $N$. These findings are in harmony with the chemical composition of both FYM and K-humate and its effect on plant growth and soil properties especially the content of available nutrients El-Koumey et al. (2017) and Zakaria (2018). The superior effect of Khumate application on the yield of grains and weight of 1000-grain compared with associated the treatment of FYM may be attributed to the high $\mathrm{K}$ content of $\mathrm{K}$ humate compared with $\mathrm{K}$ content in FYM, where $\mathrm{K}$ encourages various enzymes and photosynthesis as well as plant root development which in turn resulted in higher dry matter accumulation in grains. Moreover $\mathrm{K}$ enhances translocation of metabolites synthesized from leaves to grains. Generally, K played a major role on grains formation and structure of cereal plants. Supportive evidences with these results were reported by (Marschner, 2003).

Table (5): Weight of 1000 grains, wheat yield (grains, straw and Biological), harvest index and agronomical efficiency as affected by the studied treatments.

\begin{tabular}{|c|c|c|c|c|c|c|c|}
\hline \multirow{2}{*}{$\begin{array}{c}\text { Organic } \\
\text { fertilizers }\end{array}$} & \multirow{2}{*}{$\begin{array}{c}\text { Rate of } \\
\text { mineral } \mathrm{N} \\
\text { (kg fed. -1) }\end{array}$} & \multirow{2}{*}{$\begin{array}{c}1000 \\
\text { grain } \\
\text { weight } \\
\text { (g) }\end{array}$} & \multicolumn{3}{|c|}{ Yield (kg fed.-1) } & \multirow{2}{*}{$\begin{array}{l}\text { Harvest } \\
\text { index } \\
(\%)\end{array}$} & \multirow{2}{*}{$\begin{array}{l}\text { Agronomical } \\
\text { efficiency }\end{array}$} \\
\hline & & & Grains & Straw & Biological & & \\
\hline \multirow{4}{*}{ Without } & 0 & 35.20 & 480.0 & 920.0 & 1400.0 & 34.29 & 0.00 \\
\hline & 50 & 45.08 & 1200.0 & 2480.0 & 3680.0 & 32.61 & 14.40 \\
\hline & 75 & 46.53 & 1320.0 & 2920.0 & 4240.0 & 31.13 & 11.20 \\
\hline & 100 & 52.36 & 1480.0 & 3100.0 & 4580.0 & 32.31 & 10.00 \\
\hline \multicolumn{2}{|c|}{ Mean } & 44.75 & 1120 & 2355.0 & 3475.0 & 32.59 & 8.90 \\
\hline \multirow{4}{*}{$\begin{array}{c}\text { FYM } \\
\text { (ton fed.-1) }\end{array}$} & 0 & 42.33 & 677.2 & 1826.0 & 2503.2 & 27.06 & 0.00 \\
\hline & 50 & 50.65 & 1400.0 & 2900.0 & 4300.0 & 32.56 & 14.45 \\
\hline & 75 & 56.45 & 1440.0 & 3380.0 & 4820.0 & 29.88 & 10.17 \\
\hline & 100 & 60.00 & 1780.0 & 4200.0 & 5980.0 & 29.77 & 11.03 \\
\hline \multicolumn{2}{|c|}{ Mean } & 52.49 & 1324.3 & 3076.5 & 4400.8 & 29.81 & 8.91 \\
\hline \multirow{4}{*}{$\begin{array}{l}\text { K-humate } \\
\text { (kg fed.-1) }\end{array}$} & 0 & 49.12 & 769.8 & 1710.0 & 2479.8 & 31.04 & 0.00 \\
\hline & 50 & 55.40 & 1620.0 & 2560.0 & 4180.0 & 38.76 & 17.00 \\
\hline & 75 & 57.15 & 1900.0 & 3000.0 & 4900.0 & 38.78 & 15.07 \\
\hline & 100 & 61.45 & 2000.0 & 3560.0 & 5560.0 & 35.97 & 12.30 \\
\hline \multicolumn{2}{|c|}{ Mean } & 55.90 & 1572.45 & 2707.5 & 4279.95 & 36.14 & 11.09 \\
\hline
\end{tabular}




\begin{tabular}{|c|c|c|c|c|c|c|}
\hline L.S.D. at 5 \% & & & & & & \\
Organic fertilizers: (A) & 0.168 & 0.437 & 0.229 & 0.153 & 0.135 & 0.084 \\
Rate of mineral N: (B) & 0.194 & 0.505 & 0.265 & 0.177 & 0.156 & 0.097 \\
Interaction: (A) × (B) & 0.337 & 0.875 & 0.459 & 0.307 & 0.271 & 0.168 \\
\hline
\end{tabular}

Harvest index $(\%)=\{$ grains yield $(\mathrm{kg}$ fed.-1) $/$ biological yield (kg fed.-1) $\} \times 100$

Agronomical efficiency $=$ \{grain yield (fertilizer) - grain yield (control) $\}$ l applied nitrogen

Concerning the interaction between organic fertilizers (FYN or K-humate) and mineral $\mathrm{N}$ fertilizers levels significant increases of yield and yield components of wheat plants. Data in Table (5) revealed that the maximum values for 1000-grain weight (g) and grains yield were obtained under treatment by $100 \mathrm{~kg}$ $\mathrm{N}$ fed. ${ }^{-1}+\mathrm{K}$-humate ,while the maximum values for straw and biological yield were obtained under treatment by $100 \mathrm{~kg} \mathrm{~N}$ fed. ${ }^{-1}+$ FYM. The relative increases for FYM over control ( $\mathrm{N}$ - fertilizer at rate 0 , 50,75 and $100 \mathrm{~kg} \mathrm{~N} /$ fed. and without FYM), reached to 20.26, 12.36, 21.32 and 14.59 of 1000 -grain weight, 41.08, 16.67, 9.09 and 110.27 of grain yield and 98.48, $16.94,15.75$ and $26.19 \%$ of straw, respectively. On the other hand, The relative increases for $\mathrm{K}$-humate over control ( $\mathrm{N}$ - fertilizer at rate $0,50,75$ and $100 \mathrm{~kg} \mathrm{~N} /$ fed. and without K-humate), reached to $39.55,22.89,22.82$ and 17.36 of 1000-grain weight, $60.38,35.00,43.94$ and 35.14 of grain yield and $85.87,3.23$, 2.74 and $14.84 \%$ of straw, respectively.

Under different fertilization treatments in this study, the yield of grains were lower than those of straw. So, the calculated values of harvesting index $(\mathrm{HI}$, $\%)$ were lower than $40 \%$. The highest values of $\mathrm{HI}(38.78, \%)$ were recorded with the treatment by $75 \mathrm{~kg} \mathrm{~N}$ fed. ${ }^{-1}$ plus 5 kg fed. ${ }^{-1}$ K-humate. Dileep et al. (2014); Abd El-Kader (2016) and El-Koumey et al. (2017) reported such beneficial effect of different plant species.

Agronomical efficiency (AE) of $N$ fertilizer may be used as a good parameter to estimate the efficiency of each fertilizer unit in grains production. Data in Table (5) showed that, individual applications of $\mathbf{N}$ fertilizer, the highest $\mathrm{AE}$ value (14.40) was found with the grains of wheat plants received $50 \mathrm{~kg} \mathrm{~N}$ fed. $^{-1}$ and decreased with the increase rate of added $\mathrm{N}$. With the three rates of added $\mathrm{N}$ alone, AE values were positive with wide variation from rate to another. Recently, El-Tahlawy (2018) and Zakaria (2018) obtained similar results with wheat and maize plants respectively, under sandy soil conditions.

In addition, $\mathbf{N}$ additions at different levels, i.e., 50,75 and $100 \mathrm{~kg}$ fed. ${ }^{-1}$ in combination with either of FYM or Khumate were associated with $a$ significant increases of AE of $N$ fertilizer on grains yield compared with the individual applications of $\mathrm{N}$ (Table, 5), where the increases of $A E$ for grains of wheat plants fertilized by K-humate were higher than those result from FYM applications at the same rate of added $\mathrm{N}$. These findings are in harmony with the effect of the studied treatment on grain yield and $\mathrm{K}$ content in the used organic fertilizers. These results are in agreement with those obtained by Dileep et al. (2014); Abd El-Kader (2016) ; El-Koumey et al. (2017) and Zakaria (2018).

\section{Nutrients Concentration in Grains and Straw of Wheat plants:}

Data presented in Tables ( 6 and 7) showed that, $\mathrm{N}$ application alone at different levels slightly increased concentration of the studied macro- $(\mathrm{N}$, $P$ and $K, \%)$ and micronutrients ( $\mathrm{Fe}, \mathrm{Mn}$ and $\mathrm{Zn}, \mathrm{mg} \mathrm{kg}^{-1}$ ) in grains and straw of wheat plants, where these concentrations were increased with the increase of rate applied N-levels. This may be due to high availability of the nutrients with increase in the fertilizer application (N) which 
ultimately resulted in better root growth and increased physiological activity of roots to absorb the nutrients (Tantawy et al., 2011; Abd El-Kader, 2016 and Zakaria, 2018).

In addition, individual applications of either both FYM or K-humate to sandy soil resulted in a significant increases of $\mathrm{N}, \mathrm{P}, \mathrm{K}, \mathrm{Fe}, \mathrm{Mn}$ and $\mathrm{Zn}$ concentration in the grains and straw of wheat plants (Tables, 6 and 7). At the same individual treatments of $\mathrm{N}$-fertilizer, $\mathrm{FYM}$ and $\mathrm{K}$ humate, grains concentrations of the estimated macro- and micronutrients and protein were higher than those found in the straw. The increases effect of FYM and K-humate application alone attributed to the presence of nutrients in the added organic fertilizers and also to its effect on the soil content of available nutrients (Verlinden et al., 2009 and Nassar and Abd El-Rahaman, 2015 ). Except $\mathrm{K}$ concentration (\%), N, P, Fe, Mn and $\mathrm{Zn}$ concentration (\%) in both grains and straw of wheat plants received FYM alone were higher than those found in the plants received $\mathrm{K}$-humate. These findings were resulted from the high content of $K$ in K-humate compared with that in FYM.

The combined treatments application of $\mathbf{N}$ at different levels with either of FYM or K-humate were associated with clear and significant increases of $\mathrm{N}, \mathrm{P}, \mathrm{K}, \mathrm{Fe}$, $\mathrm{Mn}$ and $\mathrm{Zn}$ concentration in both grains and straw of wheat plants compared with any individual application of N, FYM and K-humate (Tables, 6 and 7), where the highest concentrations of these nutrients in grains and straw, were found with $\mathbf{1 0 0}$ kg N fed. ${ }^{-1}$ plus FYM followed by those found with $100 \mathrm{~kg} \mathrm{~N}_{\text {fed. }}{ }^{-1}$ plus K-humate, except $K$ concentration which appeared high values $\mathrm{K}$-humate application as a result of high content of $\mathrm{K}$ in $\mathrm{K}$-humate compared with that in FYM. These findings are in agreement with those obtained by Nassar and Abd El-Rahaman (2015); Abd El-Kader (2016) and Zakaria (2018). Generally, at the same treatment, it was found that content of $\mathrm{N}$ and $\mathrm{P}$ in the grains is higher than straw while the $K$ content in straw is higher than grains.

Table (6): Macronutrients ( N, P and K ), micronutrients ( Fe, Mn and Zn ) concentration and crude protein in grains of wheat plant as affected by the studied treatments.

\begin{tabular}{|c|c|c|c|c|c|c|c|c|}
\hline \multirow{2}{*}{$\begin{array}{c}\text { Organic } \\
\text { fertilizers }\end{array}$} & \multirow{2}{*}{$\begin{array}{c}\text { Rate of } \\
\text { mineral } \\
N(\mathbf{k g} \\
\text { fed. }-1)\end{array}$} & \multicolumn{3}{|c|}{ Macronutrients (\%) } & \multicolumn{3}{|c|}{ Micronutrients (mg kg-1) } & \multirow{2}{*}{$\begin{array}{c}\text { Crude } \\
\text { protein } \\
(\%)\end{array}$} \\
\hline & & $\mathbf{N}$ & $\mathbf{P}$ & $\mathbf{K}$ & $\mathrm{Fe}$ & Mn & Zn & \\
\hline \multirow{4}{*}{ Without } & 0 & 1.32 & 0.30 & 0.76 & 70.95 & 40.20 & 21.9 & 7.59 \\
\hline & 50 & 1.33 & 0.33 & 0.78 & 72.38 & 42.62 & 22.3 & 7.65 \\
\hline & 75 & 1.35 & 0.35 & 1.13 & 73.00 & 43.23 & 23.2 & 7.76 \\
\hline & 100 & 1.38 & 0.39 & 1.24 & 75.20 & 44.75 & 24.1 & 7.94 \\
\hline \multicolumn{2}{|c|}{ Mean } & 1.34 & 0.34 & 0.98 & 72.88 & 42.7 & 22.88 & 7.74 \\
\hline \multirow{4}{*}{$\begin{array}{c}\text { FYM } \\
\text { (ton fed.-1) }\end{array}$} & 0 & 1.55 & 0.33 & 0.91 & 76.12 & 46.15 & 23.5 & 8.91 \\
\hline & 50 & 1.67 & 0.38 & 1.07 & 80.94 & 49.23 & 25.0 & 9.60 \\
\hline & 75 & 1.85 & 0.42 & 1.18 & 82.94 & 50.57 & 26.9 & 10.64 \\
\hline & 100 & 1.92 & 0.46 & 1.29 & 85.15 & 54.34 & 30.3 & 11.04 \\
\hline \multicolumn{2}{|c|}{ Mean } & 1.75 & 0.40 & 1.11 & 81.29 & 50.07 & 26.43 & 10.05 \\
\hline \multirow{4}{*}{$\begin{array}{l}\text { K-humate } \\
\text { (kg fed.-1) }\end{array}$} & 0 & 1.41 & 0.31 & 1.12 & 73.46 & 43.50 & 22.7 & 8.11 \\
\hline & 50 & 1.54 & 0.35 & 1.20 & 76.87 & 47.64 & 24.2 & 8.86 \\
\hline & 75 & 1.63 & 0.38 & 1.25 & 79.63 & 48.89 & 25.0 & 9.38 \\
\hline & 100 & 1.77 & 0.41 & 1.32 & 80.44 & 50.14 & 27.4 & 10.18 \\
\hline
\end{tabular}


Improvement of sandy soil characteristics and its productivity of wheat ..............

\begin{tabular}{|c|c|c|c|c|c|c|c|}
\hline Mean & 1.59 & 0.36 & 1.22 & 77.6 & 47.54 & 24.83 & 9.13 \\
\hline L.S.D. at 5 \% & & & & & & & \\
Organic fertilizers: (A) & 0.032 & 0.190 & 0.032 & 0.191 & 0.084 & 1.400 & 0.557 \\
Rate of mineral N: (B) & 0.037 & 0.022 & 0.037 & 0.220 & 0.097 & 1.620 & 0.643 \\
Interaction: (A) × (B) & 0.064 & N.S & 0.064 & 0.382 & 0.168 & 2.800 & 1.115 \\
\hline
\end{tabular}

Table (7): Macronutrients ( N, P and K ), micronutrients ( Fe, Mn and $\mathrm{Zn}$ ) concentration and crude protein in straw of wheat plant as affected by the studied treatments.

\begin{tabular}{|c|c|c|c|c|c|c|c|c|}
\hline \multirow{2}{*}{$\begin{array}{c}\text { Organic } \\
\text { fertilizers }\end{array}$} & \multirow{2}{*}{$\begin{array}{l}\text { Rate of } \\
\text { mineral } \\
N(k g \\
\text { fed. }-1)\end{array}$} & \multicolumn{3}{|c|}{ Macronutrients (\%) } & \multicolumn{3}{|c|}{ Micronutrients (mg kg-1) } & \multirow{2}{*}{$\begin{array}{c}\text { Crude } \\
\text { protein } \\
(\%)\end{array}$} \\
\hline & & $\mathbf{N}$ & $\mathbf{P}$ & $\mathbf{K}$ & $\mathrm{Fe}$ & Mn & Zn & \\
\hline \multirow{4}{*}{ Without } & 0 & 1.03 & 0.20 & 0.83 & 50.1 & 22.3 & 15.25 & 5.92 \\
\hline & 50 & 1.11 & 0.23 & 0.98 & 53.4 & 25.4 & 16.30 & 6.38 \\
\hline & 75 & 1.13 & 0.25 & 1.20 & 56.7 & 28.2 & 18.00 & 6.50 \\
\hline & 100 & 1.17 & 0.28 & 1.27 & 58.1 & 28.8 & 19.29 & 6.73 \\
\hline \multicolumn{2}{|c|}{ Mean } & 1.11 & 0.24 & 1.07 & 54.58 & 26.18 & 17.21 & 6.38 \\
\hline \multirow{4}{*}{$\begin{array}{c}\text { FYM } \\
\text { (ton fed.-1) }\end{array}$} & 0 & 1.15 & 0.27 & 1.17 & 57.6 & 28.1 & 19.89 & 6.61 \\
\hline & 50 & 1.20 & 0.30 & 1.19 & 59.8 & 29.6 & 20.96 & 6.90 \\
\hline & 75 & 1.30 & 0.32 & 1.28 & 61.2 & 31.2 & 21.31 & 7.49 \\
\hline & 100 & 1.40 & 0.36 & 1.32 & 62.7 & 32.6 & 21.63 & 8.05 \\
\hline \multicolumn{2}{|c|}{ Mean } & 1.26 & 0.31 & 1.24 & 60.33 & 30.38 & 20.95 & 7.26 \\
\hline \multirow{4}{*}{$\begin{array}{l}\text { K-humate } \\
\text { (kg fed.-1) }\end{array}$} & 0 & 1.11 & 0.24 & 1.31 & 55.2 & 26.2 & 18.22 & 6.38 \\
\hline & 50 & 1.19 & 0.26 & 1.36 & 58.1 & 27.4 & 20.16 & 6.84 \\
\hline & 75 & 1.22 & 0.29 & 1.40 & 60.0 & 29.7 & 20.48 & 7.02 \\
\hline & 100 & 1.24 & 0.33 & 1.49 & 60.5 & 30.9 & 20.55 & 7.13 \\
\hline \multicolumn{2}{|c|}{ Mean } & 1.19 & 0.28 & 1.39 & 58.45 & 28.55 & 19.85 & 6.84 \\
\hline \multirow{3}{*}{\multicolumn{2}{|c|}{$\begin{array}{l}\text { L.S.D. at } 5 \% \\
\text { Organic fertilizers: }(A) \\
\text { Rate of mineral N: }(B) \\
\text { Interaction: }(A) \times(B)\end{array}$}} & 0.034 & 0.027 & 0.032 & 0.803 & 0.027 & 0.191 & 0.191 \\
\hline & & 0.039 & 0.031 & 0.037 & 0.928 & 0.031 & 0.336 & 0.220 \\
\hline & & 0.068 & N.S & 0.064 & 1.607 & 0.054 & 0.382 & 0.382 \\
\hline
\end{tabular}

\section{Crude Protein (\%):}

The crude protein (\%) in grains and straw of wheat plants increased significant with increase individual application rate of mineral $\mathrm{N}$ and also as a result of individual application of FYM and K-humate, where the high protein content was found with the individual application of $\mathrm{N}$ at rate of $100 \mathrm{~kg}$ fed. ${ }^{-1}$ compared with the individual application of FYM and K-humate (Tables, 6 and 7). Individual application of FYM resulted in a more increase of wheat plants (grains and straw) content of protein compared with that found in the plants fertilized by
K-humate. These findings are in harmony with the chemical composition of the added the organic fertilizers, especially the content of $\mathrm{N}$. These results are in agreement with those obtained by Nassar and Abd El-Rahaman (2015); Abd ElKader (2016) and Zakaria (2018).

Data in Tables (6 and 7) show a significant increases of wheat plants (grains and straw) content (\%) of protein followed by N + FYM and N+ K-humate applications together compared with those associated with the individual treatments of these. Generally, the 
highest content of protein was found in the wheat plants (grains and straw) received $100 \mathrm{~kg} \mathrm{~N}$ fed. $^{-1}$ plus FYM followed by that found in the plants fertilized with $100 \mathrm{~kg} \mathrm{~N}^{\mathrm{N}}$ fed. $^{-1}$ plus Khumate. Also, at the same treatment of $\mathrm{N}$, FYM and K-humate alone or together, protein content of grains was higher than that found in the straw. In this respect, Nassar and Abd El-Rahaman (2015) ; Abd El-Kader (2016) and Zakaria (2018) obtained similar results.

\section{Nutrients Uptake in Grains and} Straw of Wheat Plants:

The effect of various nitrogen fertilizers, i.e., FYM and K-humate on macro- ( $N, P$ and $K$ ) and micro- (Fe, Mn and $\mathrm{Zn}$ ) nutrients uptake in grains and straw as well as apparent nitrogen recovery efficiency (ANRE) of wheat plants are presented in Tables (8 and 9). Individual applications of $\mathrm{N}$ were associated with a significant increases of the determined macro- and micronutrients uptake by grains and straw of wheat plants. These increases resulted from the enhanced effect of $\mathrm{N}$ fertilizer on obtained dry matter yields of grains and straw as aforementioned by Elbaalawy (2010); Tantawy et al. (2011) Abd El-Kader (2016) and Zakaria (2018). Similar increases of macro- and micronutrients uptake by grains and straw of wheat plants were found as a result of FYM or K-humate applications alone, where the found increases in the plants received FYM were higher than those found in the plants fertilized by K-humate, except $\mathrm{K}$ uptake which appeared high uptake in the plants fertilized by K-humate. The found increases of nutrients uptake by wheat plants fertilized by FYM and Khumate attributed to their effect on plant growth and soil content of available nutrients as mentioned before that by Nassar and Abd El-Rahaman (2015); Abd El-Kader (2016) and Zakaria (2018).

Table (8): Macronutrients ( N, P and K), micronutrients (Fe, Mn and $\mathrm{Zn}$ ) uptake and apparent nitrogen recovery efficiency (ANRE) in grains of wheat plant as affected by the studied treatments.

\begin{tabular}{|c|c|c|c|c|c|c|c|c|}
\hline \multirow{2}{*}{$\begin{array}{c}\text { Organic } \\
\text { fertilizers }\end{array}$} & \multirow{2}{*}{$\begin{array}{c}\text { Rate of } \\
\text { mineral N } \\
\text { (kg fed. -1) }\end{array}$} & \multicolumn{3}{|c|}{$\begin{array}{l}\text { Macronutrients } \\
\text { (kg fed.-1) }\end{array}$} & \multicolumn{3}{|c|}{ Micronutrients ( $\mathrm{g}$ fed.-1) } & \multirow{2}{*}{ ANRE } \\
\hline & & $\mathbf{N}$ & $\mathbf{P}$ & K & $\mathrm{Fe}$ & Mn & $\mathrm{Zn}$ & \\
\hline \multirow{4}{*}{ Without } & 0 & 6.34 & 1.44 & 3.65 & 340.56 & 192.96 & 105.14 & --- \\
\hline & 50 & 15.96 & 3.96 & 9.36 & 868.56 & 511.44 & 267.6 & 19.24 \\
\hline & 75 & 17.82 & 4.62 & 14.92 & 963.6 & 570.63 & 306.23 & 15.31 \\
\hline & 100 & 20.42 & 5.77 & 18.35 & 1112.96 & 662.31 & 356.68 & 14.08 \\
\hline \multicolumn{2}{|c|}{ Mean } & 15.14 & 3.95 & 11.57 & 821.42 & 484.37 & 258.91 & 12.16 \\
\hline \multirow{4}{*}{$\begin{array}{c}\text { FYM } \\
\text { (ton fed.-1) }\end{array}$} & 0 & 10.49 & 2.23 & 6.16 & 515.48 & 312.52 & 159.14 & --- \\
\hline & 50 & 23.38 & 5.32 & 14.98 & 1133.16 & 689.22 & 350.00 & 25.78 \\
\hline & 75 & 26.64 & 6.05 & 16.99 & 1194.34 & 728.15 & 387.36 & 21.53 \\
\hline & 100 & 34.18 & 8.19 & 22.96 & 1515.67 & 967.25 & 539.34 & 23.69 \\
\hline \multicolumn{2}{|c|}{ Mean } & 23.67 & 5.45 & 15.27 & 1089.66 & 674.29 & 358.96 & 17.75 \\
\hline \multirow{4}{*}{$\begin{array}{l}\text { K-humate } \\
\text { (kg fed.-1) }\end{array}$} & 0 & 10.85 & 2.39 & 8.62 & 565.49 & 334.91 & 174.74 & --- \\
\hline & 50 & 24.94 & 5.67 & 19.44 & 1245.3 & 771.77 & 392.04 & 28.18 \\
\hline & 75 & 30.97 & 7.22 & 23.75 & 1512.97 & 928.91 & 475.00 & 26.83 \\
\hline & 100 & 35.67 & 6.20 & 26.40 & 1608.8 & 1002.80 & 548.0 & 24.82 \\
\hline \multicolumn{2}{|c|}{ Mean } & 25.61 & 5.87 & 19.55 & 1233.139 & 759.60 & 397.45 & 19.96 \\
\hline
\end{tabular}


Improvement of sandy soil characteristics and its productivity of wheat

\begin{tabular}{|c|c|c|c|c|c|c|c|}
\hline L.S.D. at 5 \% & & & & & & & \\
Organic fertilizers: (A) & 0.519 & 0.289 & 0.386 & 0.474 & 0.474 & 0.038 & 0.790 \\
Rate of mineral N: (B) & 0.599 & 0.334 & 0.445 & 0.011 & 0.011 & 0.508 & 0.912 \\
Interaction: (A) × (B) & 1.038 & 0.578 & 0.772 & 0.948 & 0.329 & 0.076 & 1.580 \\
\hline
\end{tabular}

Table (9): Macronutrients ( N, P and K), micronutrients (Fe, Mn and $\mathrm{Zn}$ ) uptake and apparent nitrogen recovery efficiency (ANRE) in straw of wheat plant as affected by the studied treatments.

\begin{tabular}{|c|c|c|c|c|c|c|c|c|}
\hline \multirow{2}{*}{$\begin{array}{l}\text { Organic } \\
\text { fertilizers }\end{array}$} & \multirow{2}{*}{$\begin{array}{c}\text { Rate of } \\
\text { mineral } N \\
\text { (kg fed. }-1)\end{array}$} & \multicolumn{3}{|c|}{$\begin{array}{c}\text { Macronutrients } \\
\text { (kg fed.-1) }\end{array}$} & \multicolumn{3}{|c|}{ Micronutrients (g fed.-1) } & \multirow{2}{*}{ ANRE } \\
\hline & & $\mathbf{N}$ & $\mathbf{P}$ & $\mathrm{K}$ & $\mathrm{Fe}$ & $\mathrm{Mn}$ & $\mathrm{Zn}$ & \\
\hline \multirow{4}{*}{ Without } & 0 & 9.47 & 1.84 & 7.64 & 460.92 & 205.16 & 140.30 & --- \\
\hline & 50 & 27.53 & 5.37 & 24.30 & 1324.33 & 629.92 & 404.24 & 36.12 \\
\hline & 75 & 33.00 & 7.30 & 35.04 & 1655.64 & 823.44 & 525.61 & 31.37 \\
\hline & 100 & 36.26 & 8.68 & 39.40 & 1801.44 & 892.72 & 598.04 & 26.79 \\
\hline \multicolumn{2}{|c|}{ Mean } & 26.57 & 5.80 & 26.59 & 1310.58 & 637.81 & 417.05 & 23.57 \\
\hline \multirow{4}{*}{$\begin{array}{c}\text { FYM } \\
\text { (ton fed.-1) }\end{array}$} & 0 & 21.00 & 4.93 & 21.36 & 1051.78 & 513.11 & 363.20 & ---- \\
\hline & 50 & 34.80 & 8.70 & 34.51 & 1733.92 & 858.40 & 607.84 & 27.60 \\
\hline & 75 & 34.94 & 10.82 & 43.27 & 2068.55 & 1054.56 & 720.30 & 18.59 \\
\hline & 100 & 58.79 & 15.11 & 55.44 & 2633.42 & 1369.16 & 908.49 & 37.79 \\
\hline \multicolumn{2}{|c|}{ Mean } & 39.64 & 9.89 & 38.65 & 1871.92 & 948.81 & 649.98 & 21.00 \\
\hline \multirow{4}{*}{$\begin{array}{l}\text { K-humate } \\
\text { (kg fed.-1) }\end{array}$} & 0 & 18.98 & 4.08 & 22.40 & 943.91 & 448.02 & 313.52 & ---- \\
\hline & 50 & 30.46 & 6.66 & 34.82 & 1487.36 & 701.44 & 516.09 & 22.96 \\
\hline & 75 & 36.60 & 8.70 & 42.00 & 1800.00 & 891.00 & 614.6 & 23.49 \\
\hline & 100 & 44.15 & 11.75 & 53.04 & 2153.73 & 1100.04 & 727.91 & 25.17 \\
\hline \multicolumn{2}{|c|}{ Mean } & 32.55 & 7.80 & 38.06 & 1596.25 & 785.13 & 542.90 & 17.91 \\
\hline \multicolumn{2}{|c|}{ L.S.D. at $5 \%$} & & & & & & & \\
\hline \multirow{2}{*}{\multicolumn{2}{|c|}{$\begin{array}{l}\text { Organic fertilizers: }(A) \\
\text { Rate of mineral N: (B) }\end{array}$}} & 0.923 & 0.973 & 1.075 & 0.639 & 0.837 & 0.100 & N.S \\
\hline & & 1.065 & 0.754 & 1.240 & 0.749 & 0.740 & 0.198 & 0.314 \\
\hline \multicolumn{2}{|c|}{ Interaction: $(A) \times(B)$} & 1.846 & 0.947 & 2.151 & 0.278 & 0.675 & 0.200 & 0.472 \\
\hline
\end{tabular}

Data in Tables (8 and 9) also show that, combined applications of $\mathrm{N}+\mathrm{FYM}$ and $\mathrm{N}+\mathrm{K}$-humate resulted in a significant increases of macro- and micronutrients uptake by grains and straw of wheat plants compared the individual applications of these three fertilizers. The found increases of nutrients uptake in the plants fertilized by $\mathrm{N}+\mathrm{FYM}$ were higher than those found in the plants received $\mathrm{N}+\mathrm{K}$-humate, except $K$ uptake. In general under different studied treatments, nutrients uptake by straw were higher than those uptake by grains. Soliman (2007); Verlinden et al. (2009) and Abd El-Kader (2016) found similar results with different organic fertilizers.

Data illustrated in Tables (8 and 9) show that, apparent nitrogen recovery efficiency (ANRE) was defined as the ratio of total content of nitrogen (uptake) in plants receiving different treatments minus total content of nitrogen (uptake) without treatments application (control), then divided by nitrogen application as $\mathrm{kg}$ fed. $^{-1}$ is then multiplied by one hundred. Results indicate that 
application of both organic and mineral $\mathrm{N}$ fertilizers to the soil increased apparent nitrogen recovery efficiency as compared to control treatments, and the applied high rate was superior compared to the low one. With regard to the different treatments, results indicated that the highest values of (ANRE) in grains for wheat plants were recorded in case of applying K-humate as compared to FYM and mineral fertilizer, while the highest values of (ANRE) in straw for wheat plants were recorded in case of applying mineral fertilizer as compared to FYM and K-humate, high rates were more beneficial. As for the effect of mineral and organic (FYM and K-humate) fertilizers, data indicate that, for both studied seasons, the application of all fertilizers significantly increased (ANRE) as compared to control. The treatments of fertilizers may be generally arranged as follows: K-humate > FYM > mineral fertilizer, in grains while arranged as follows: mineral fertilizer > FYM >Khumate, in straw. The same trend was observed with all fertilizers application in two successive seasons. In this connection, Quanbao et al. (2007) and Mwangi (2010) obtained similar results.

\section{Soil Content of Available Macro-} and Micronutrients:

The soil contents of available macroi.e., $N, P$ and $K$ (kg fed..$\left.^{-1}\right)$ and micronutrients, i.e., $\mathrm{Fe}, \mathrm{Mn}$ and $\mathrm{Zn}$ (g fed. $^{-1}$ ) affected by the studied treatments as listed in Table (10) show that, the soil content of available nutrients were decreased with the increase rate of added $\mathbf{N}$ fertilizer individually, except the content of available $\mathrm{N}$ which recorded small increases as a result of $N$ application. In this respect, Tantawy et al. (2011) obtained similar results with rice plants fertilized by different forms of mineral nitrogen fertilizers. The decreases in the soil content of available
$\mathrm{P}, \mathrm{K}, \mathrm{Fe}, \mathrm{Mn}$ and $\mathrm{Zn}$ after harvesting of wheat plants fertilized by ammonium nitrate at rates of 50,75 and $100 \mathrm{~kg} \mathrm{fed}^{-1}$ attributed to the high uptake of these nutrients by wheat plants received $\mathrm{N}$ fertilizer. These decreases were increased with the increase rate of added N.

Individual applications of FYM or Khumate were associated with an increases of sandy soil content of available $\mathrm{N}, \mathrm{P}, \mathrm{K}, \mathrm{Fe}, \mathrm{Mn}$ and $\mathrm{Zn}$ (Table, 10), where the found increases of these contents as a result of FYM application were higher than those associated with the treatment of K-humate, except the soil content of available $K$ which takes reversible trend. The application of FYM increased of $P$ content, and possibly by increasing retention of $P$ in soil. $A$ positive effect of $F Y M$ on $P$ availability was also noticed by Roy et al. (2001). Lal et al. (2000) reported that with the increase in incubation time the $K$ mineralized increased significantly and raised the available $K$ in soil due to release of more of organically bound potassium in course of decomposition of organic waste. Vaughan and Ord (1991) found that inhibition of urease activity by humic acid led to reduced $\mathrm{N}$ losses thereby increase $\mathbf{N}$ concentration in soil. Hua et al. (2008) reported that humic substances in soil can decrease $P$ fixation and increase the $P$ uptake of plants. Similarly, the increased soil available $\mathrm{K}$ observed may be attributed to the reduced $\mathrm{K}$ fixation as well as release of fixed $\mathrm{K}$ by humic acid.

Finally, data in Table (10) show that, the combined applications of N + FYM and $\mathbf{N}+$ K-humate appeared a wide variations in their effects, on sandy soils content of available N, P, K, Fe, Mn and $\mathrm{Zn}$, where these application resulted in a slight increase of the soil content of 
available nutrients compared with these resulted from the individual applications of FYM and K-humate. At the same application rate of $\mathrm{N}$, sandy soil fertilized by FYM have a high content of available $\mathrm{N}, \mathrm{P}, \mathrm{Fe}, \mathrm{Mn}$ and $\mathrm{Zn}$. On the other hand, the high soil of available $K$ was found in the soil received K-humate. Senn (1991) revealed that humateas natural organic substances high in trace elements necessary for development of plant life and soil health. Further humic acid binds to soil colloidal surfaces, promotes heavy metal absorption ( $\mathrm{Zn}, \mathrm{Mn}, \mathrm{Cu}, \mathrm{Fe}$ ) to soil minerals and enhance their availability. Govindasamy and
Chandrasekaran (2002) reported that the application of humic acid increases the concentration in soil and enhance the uptake of $\mathrm{Fe}, \mathrm{Mn}$ and $\mathrm{Zn}$ by rice. Moharanaa et al. (2017) found the importance of application of FYM in improving soil properties and maintaining micronutrients availability in soil and their uptake by wheat for sustainable crop production. In this respect, similar results were obtained by Elbaalawy (2010); Abd El-Kader (2016) ; El-Koumey et al. (2017) and Zakaria (2018) with many sources of organic fertilizers.

Table (10): Macronutrients ( N, P and K) and micronutrients ( $\mathrm{Fe}, \mathrm{Mn}$ and $\mathrm{Zn}$ ) content in sandy soil as affected by the studied treatments, after wheat plants harvesting.

\begin{tabular}{|c|c|c|c|c|c|c|c|}
\hline \multirow{2}{*}{$\begin{array}{c}\text { Organic } \\
\text { fertilizers }\end{array}$} & \multirow{2}{*}{$\begin{array}{c}\text { Rate of } \\
\text { mineral } N \\
\text { (kg fed. }-1)\end{array}$} & \multicolumn{3}{|c|}{$\begin{array}{l}\text { Available macronutrients } \\
\qquad(\mathrm{kg} \text { fed.-1) }\end{array}$} & \multicolumn{3}{|c|}{$\begin{array}{l}\text { Available micronutrients } \\
\qquad(\mathrm{g} \text { fed. }-1)\end{array}$} \\
\hline & & $\mathbf{N}$ & $\mathbf{P}$ & K & $\mathrm{Fe}$ & Mn & $\mathrm{Zn}$ \\
\hline \multirow{4}{*}{ Without } & 0 & 11.68 & 1.90 & 51.50 & 3.98 & 2.50 & 0.65 \\
\hline & 50 & 13.20 & 1.80 & 51.15 & 3.90 & 2.40 & 0.60 \\
\hline & 75 & 14.10 & 1.68 & 50.70 & 3.65 & 2.22 & 0.53 \\
\hline & 100 & 15.70 & 1.50 & 50.20 & 3.50 & 2.05 & 0.50 \\
\hline \multicolumn{2}{|c|}{ Mean } & 13.67 & 1.72 & 50.89 & 3.76 & 2.29 & 0.57 \\
\hline \multirow{4}{*}{$\begin{array}{c}\text { FYM } \\
\text { (ton fed.-1) }\end{array}$} & 0 & 13.10 & 2.18 & 53.81 & 4.82 & 2.80 & 0.85 \\
\hline & 50 & 13.65 & 2.15 & 53.40 & 4.70 & 2.75 & 0.81 \\
\hline & 75 & 15.35 & 2.10 & 52.75 & 4.45 & 2.68 & 0.76 \\
\hline & 100 & 16.18 & 2.05 & 52.33 & 4.28 & 2.59 & 0.72 \\
\hline \multicolumn{2}{|c|}{ Mean } & 14.75 & 2.12 & 53.07 & 4.56 & 2.71 & 0.79 \\
\hline \multirow{4}{*}{$\begin{array}{l}\text { K-humate } \\
\text { (kg fed.-1) }\end{array}$} & 0 & 12.95 & 2.10 & 56.75 & 4.61 & 2.68 & 0.80 \\
\hline & 50 & 13.30 & 2.10 & 56.05 & 4.50 & 2.66 & 0.77 \\
\hline & 75 & 14.65 & 2.06 & 55.25 & 4.35 & 2.60 & 0.73 \\
\hline & 100 & 15.98 & 2.02 & 54.10 & 4.18 & 2.58 & 0.70 \\
\hline \multicolumn{2}{|c|}{ Mean } & 14.22 & 2.07 & 55.54 & 4.41 & 2.63 & 0.75 \\
\hline
\end{tabular}




\begin{tabular}{|c|c|c|c|c|c|c|}
\hline L.S.D. at 5 \% & & & & & & \\
Organic fertilizers: (A) & 0.077 & 0.053 & 0.395 & 0.161 & 0.047 & 0.028 \\
Rate of mineral N: (B) & 0.089 & 0.062 & 0.342 & 0.186 & 0.054 & 0.033 \\
Interaction: (A) × (B) & 0.155 & 0.107 & 0.684 & 0.322 & 0.095 & 0.057 \\
\hline
\end{tabular}

Soil Bulk Density, Total Porosity and Its Content of Organic Matter:

The presented data in Table (11) show that, the soil content of organic matter "OM" (\%) was slightly decreased as a result of different application rates of $\mathrm{N}$ fertilizer either alone or together with FYM and K-humate. For example the soil content of OM was decreased from 0.39 $\%$ in unfertilized soil to $0.37 \%$ in the soil received $100 \mathrm{~kg} \mathrm{~N}$ fed. ${ }^{-1}$. These decreases in the soil content of $\mathrm{OM}$ as a result of $\mathrm{N}$ applications attributed to activation effect of $\mathrm{N}$ on the biological activity which played a major role on the increase decomposition rate of soil organic matter. On the other hand, individual application of FYM and K-humate resulted in a slight increase in the soil content of OM with the superior increase effect of FYM application compared with that resulted from K-humate application. This trend may be resulted from the high stable of OM presented in FYM compared with that in K-humate. Before that, Senn (1991); Seddik (2006) and Shah et al. (2013) obtained similar results.

Table (11): Bulk density (g cm-3), total porosity (\%) and organic matter (\%) in sandy soil as affected by the studied treatments, after wheat plants harvesting.

\begin{tabular}{|c|c|c|c|c|}
\hline $\begin{array}{l}\text { Organic } \\
\text { fertilizers }\end{array}$ & $\begin{array}{c}\text { Rate of } \\
\text { mineral N } \\
\text { (kg fed. }-1)\end{array}$ & $\begin{array}{l}\text { Bulk density } \\
\text { (g cm-3) }\end{array}$ & $\begin{array}{c}\text { Total porosity } \\
\text { (\%) }\end{array}$ & $\begin{array}{c}\text { Organic matter } \\
\text { (\%) }\end{array}$ \\
\hline \multirow{4}{*}{ Without } & 0 & 1.80 & 32.08 & 0.39 \\
\hline & 50 & 1.80 & 32.08 & 0.39 \\
\hline & 75 & 1.83 & 30.94 & 0.37 \\
\hline & 100 & 1.85 & 30.19 & 0.37 \\
\hline \multicolumn{2}{|c|}{ Mean } & 1.82 & 31.32 & 0.38 \\
\hline \multirow{4}{*}{$\begin{array}{c}\text { FYM } \\
\text { (ton fed.-1) }\end{array}$} & 0 & 1.65 & 37.74 & 0.46 \\
\hline & 50 & 1.70 & 35.85 & 0.44 \\
\hline & 75 & 1.72 & 35.09 & 0.44 \\
\hline & 100 & 1.78 & 32.83 & 0.42 \\
\hline \multicolumn{2}{|c|}{ Mean } & 1.71 & 35.38 & 0.44 \\
\hline \multirow{4}{*}{$\begin{array}{l}\text { K-humate } \\
\text { (kg fed.-1) }\end{array}$} & 0 & 1.70 & 35.85 & 0.45 \\
\hline & 50 & 1.72 & 35.09 & 0.42 \\
\hline & 75 & 1.78 & 32.83 & 0.42 \\
\hline & 100 & 1.80 & 32.08 & 0.40 \\
\hline \multicolumn{2}{|c|}{ Mean } & 1.75 & 33.96 & 0.42 \\
\hline
\end{tabular}




\begin{tabular}{|c|c|c|c|}
\hline L.S.D. at 5 \% & & & \\
Organic fertilizers: (A) & 0.025 & 0.145 & 0.017 \\
Rate of mineral N: (B) & 0.029 & 0.168 & 0.019 \\
Interaction: (A) $\times$ (B) & 0.051 & 0.291 & 0.034 \\
\hline
\end{tabular}

Real density $=2.65 \mathrm{~g} \mathrm{~cm}-3$

Data of soil bulk density $\left(\mathrm{g} \mathrm{cm}^{-3}\right)$ and total porosity (\%) in relation with the studied treatments as listed in Table (11) may be summarized in the following points: 1- Increasing rate of added $\mathrm{N}$ fertilizer alone and in together were associated with a slight increase of soil bulk density and increased its total porosity which resulted from the decrease in the soil content of organic matter at different rates of added N, 2Individual application of FYM and Khumate resulted in a decrease of soil bulk density and increased total porosity which resulted from the aggregation effect of these organic matter, where the found decrease in soil bulk density and increased total porosity resulted from FYM application were higher than those resulted from K-humate application, also this trend is in harmony with the effect of these treatments on the soil content of $\mathrm{OM}$, and 3- The combined applications of $\mathrm{N}+\mathrm{FYM}$ and $\mathrm{N}+\mathrm{K}$-humate decreased soil bulk density and increased total porosity compared with those in the control treatment and individual applications of $\mathbf{N}$, but have high decrease of soil bulk density and low porosity compared with the individual applications of either FYM or K-humate. These results are in agreement with those obtained by Mikkelsen (2005) ; Dileep et al. (2014) and Moharanaa et al. (2017).

\section{Conclusion:}

From the abovementioned results it could be concluded that, FYM and Khumate as soil fertilizers enhanced the soil physical and chemical properties and may be the bedding materials of root zone area as well as, to some extent, the availability of nutrients in soil which positively reflected on the productivity (quantities and quality) of wheat plants, under sandy soil condition. The best treatment with regard to improving soil properties as well as increasing wheat (grains and straw) yield and nutrients uptake was the combined treatment of $100 \mathrm{~kg} \mathrm{~N}$ fed. $^{-1}+$ FYM followed by $100 \mathrm{~kg}$ $\mathrm{N}$ fed. ${ }^{-1}+\mathrm{K}$-humate.

\section{REFERENCES}

Abd El-Aal, M. A. M. (2018). Studies on improving of some desertic soil properties and their implications on plants. M.Sc. Thesis Fac. of Agric., Benha Univ., Egypt.

Abd El-Kader, N. (2016). The combined effect of urea and organic acid on some soil properties, yield and nutrient uptake by wheat crop. Egypt. J. Soil Sci., 56 (2): 281-294.

Ali, S. A., M. A. Hamza, G. Amin, M. Fayez, M. El-Tahan and N. A. Hegazi (2005). Production of biofertilizers using baker's yeast effluent and their application to wheat and barley grown in north Sinai deserts. Archives of Agronomy and Soil Sci., 51 (6): 589 604.

A.O.A.C. (1990)." Association of Official Methods of Analysis Chemists, Official Methods of Analysis ." $5^{\text {th }}$ Ed. Washington, D. C. , USA.

Basak, R.K. (2006). " Fertilizers" Kalyani Publishers, Ludhiana-New Delhi, Nodia (U. P.), Hyderabad, Chennai, Calcutta, Cuttack.

Brunetti, G., C. Plaza and N. Seneri (2005). Oliva pomace amendment in mediterranean conditions. Effect on soil and humic acid properties and 
wheat (Triticum astivum L.) yield. J. Agric. Food Chem., 53 (17): 6730 6737.

Chapman, H. O. and P. E. Pratt (1961)." Methods of Analysis for Soil, Plant and Water ". California Univ., Div. Agric. Sci., Davis, California, USA.

Cottenie, A., M. Verloo, L. Kiekens, G. Velghe and R. Camerlyek (1982). "Chemical Analysis of Plants and Soils". Laboratory of Analytical and Agrochemistry, State Univ. Ghent, Belgium.

Dileep, K., A. P. Singh, P. Raha and C. M. Singh (2014). Effects of potassium humate and chemical fertilizers on growth, yield and quality of rice (oryza sativa I.). Bangladesh J. Bot. 43(2): 183-189.

Elbaalawy, A. M. (2010). Studies on plant nutrition. M.Sc. Thesis Fac. of Agric., Menuofiya Univ., Egypt.

El-Koumey, B. Y., F. S. El-Shafei, M. M. Shehata and S. S. Ekalawey (2017). Effect of farmyard manure and different sources of $P$ and $K$ on some macronutrients in soil and plant. Menuofia J. Soil Sci., 2: 187-200.

El-Tahlawy, Y. A. (2018). Effect of microbial additives and compost tea on growth and productivity of wheat plants fertilized by mineral nitrogen in sandy soil. Menoufia J. Soil Sci., 3: 301-316.

FAO (2011). Food and Agriculture Organization of United Nation. The State of Food and Agriculture. Women in Agriculture. Closing the Gender gap for Development.

Gomez, K. A. and A. A. Gomez (1984)." Statistical Procedures for Agricultural ", Research , $2^{\text {nd }}($ Ed.) John Wily and Sons, New York.

Govindasamy, R. and S. Chandrasekaran (2002). Effect of graded levels of humic acid with and without $\mathrm{N}$ on the performance of low land rice. p. 5 . Inter. National seminar on recent trends on the use of humic substances for sustainable agriculture, Annamalai University, Tamil Nadu.

Hua, Q. X., J. Y. Li, J. M. Zhou, H. Y. Wang, C. W. Du and X. Q. Chen (2008). Enhancement of phosphorus solubility by humic substances in ferrosols . Pedosphere, 18: 533-538.

Jones, C. A., J. S. Jacobsen and A. Nugaas (2007). Effect of low-rate commercial humic acids on phosphorus availability, micronutrient uptake and spring wheat yield. Comm. Soil Plant Anal. 38: 921 - 933.

Kim, H. T. (1996). "Soil Sampling, Preparation and Analysis". Marcel Dekker Inc., New York.

Kumar, D., A. P. Singh, P. Raha, A. Rakshit, C. M. Singh and P. Kishor (2013). Potassium humate: A potential soil conditioner and plant growth promoter. International J. Agriculture, Env. and Biotech., 6: 441 - 446.

Lal, J. K., B. Mishra and A. K. Sarkar (2000). Effect of plant residues incorporation on specific microbial groups and availability of some plant nutrients in soil. J. Indian Soc. Soil Sci., 48:67-71.

Marschner, H. (2003). " Mineral Nutrition of Higher Plants". Academic Press, Harcount Brace Janovisch Publishers. New York.

Mikkelsen, R. L. (2005). Humic materials for agriculture. Better Crops, 89 (3): 610.

Moharanaa, P. C., B. M. Sharmab and D. R. Biswas (2017). Changes in the soil properties and availability of micronutrients after six-years application of organic and chemical fertilizers using STCR-based targeted yield equations under pearl milletwheat cropping system. J. of Plant Nutrition, 40 (2): 165-176.

Montaser, F. A., E. I. Mamdoh and M. M. Kadry (2011). Induction of systemic resistance of benzothiadiazole and humic acid in soya bean plants 
against fusarium wilt disease. $\mathrm{J}$. Mycobiology, 39 (4): 290 - 298.

Mwangi, T.J. (2010). Improving and sustaining soil fertility by use of farm yard manure and inorganic fertilizers for economical maize production in West Pokot, Kenya. World J. Agric. Sci., 6 (3): 313-321.

Nassar, K. E. and L. A. Abd El-Rahman (2015). Impact of compost and methods of potassium humate application on wheat. Menoufia J. Soil Sci., 40 (5): 1377-1385.

Page, A. L., R. H. Miller and D. R. Keeney (1982)." Methods of Soil Analysis". Amer. Soc. of Agron., Madison, Wisconsin, USA.

Quanbao, Y., Z. Hongcheng, W. Haiyan, Z. Ying, W. Benfo, $X$. Ke, H. Zhongyang and D. Qigen (2007). Effects of nitrogen fertilizer on nitrogen use efficiency and yield of rice under different soil conditions. Agric. China, 1, 30-36.

Roy, S. K., R. C. Sharma and S. P. Trehan (2001). Integrated nutrient management by using farmyard manure and fertilizers in potato sunflower-paddy rice rotation in the Punjab. J Agric. Sci., 137:271-278.

Seddik, W. M. A. (2006). Effect of organic manures and feldspar application on some sandy soil physical and chemical properties and their refection on peanut productivity. J. Agric. Sci., Mansoura Univ., Egypt, 33: 6675 - 6687.

Senn, T. L. (1991). Humates in agriculture. Agron. Sustain. Dev., 25(2):183-191.

Shah, S. A., W. Mohammad, S.M. Shah and M. S. Shafi (2013). Effect of organic and chemical nitrogen fertilizers on grain yield and yield components of wheat and soil fertility. Sci. J. Agron. Plant Breed, 1 (2): 37 48.

Singh, M. V., N. Kumar and B. N. Mishra (2013). Integrated use of nitrogen and FYM on yield, nutrient uptake and economics of maize in eastern Uttar Pradesh. Ann. Of Plant and Soil Res., 15 (2): 128-130.

Soliman, E. M. (2007). Integrated effect of some mineral and organic fertilizers on the productivity of wheat grown in a sandy soil. Egypt. J. of Appl. Sci., 22 (6B): 798-808.

Tantawy- Manal, F., A. Kh. Amer and Kadria M. El - Azab (2011). Effect of fertilization with bio - and mineral - $\mathrm{N}$ on yield and yield component of rice grown on a clayey soil. Menoufia J. Agric. Res., 36 (3): 757 - 774 .

Vaughan, D. and B. G. Ord (1991). Influence of natural and synthetic humic substances on the activity of urease. J. Soil Sci., 42: 17-23.

Verlinden, G., B. Pycke, J. Mertens, F. Debersaques, K. Verheyen, G. Baert, J. Bries and G. Haesaert (2009). Application of humic substances results in onsistent increases in crop yield and nutrient uptake. J. Plant Nutr., 32: 1407-1426.

Yusron, M. and I. R. Phillips (1997). Nitrogen leaching from urea and ammonium fertilizers under uncropped and cotton cropped conditions. Indonesian J. Crop Sci., 12 (1): $23-33$.

Zakaria, S. M. (2018). Response of maize plants to different $\mathrm{N}$ - sources and foliar application of potassium humate. Menoufia J. Soil Sci., 3: 101119. 
تحسين خواص الأرض الرملية و إنتاجيتها من القمح بإستخدام التسميد العضوي والنيتروجين المعدني

\section{سهام يوسف محمد أبوستيث}

معهد بحوث الأراضي و المياه و البيئة ـ مركز البحوث البويثئ الزراعية ـ الجيزة - ج. م. ع.

الملخص العربي

أُجريت تجربة حقلية علي الأرض الرملية في محطة البحوث الزراعية بالإسماعيلية ـ محافظة الإسماعيلية - مصر،

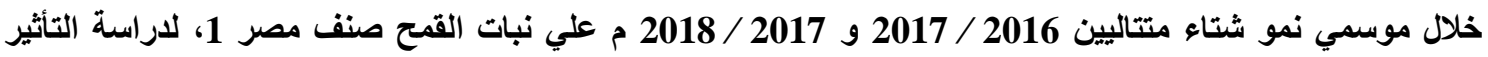
المنفرد و المشترك لإستخدام الأسمدة العضوية ( السماد البلدي أو هيومات البوتاسيوم) و مستويات مختلفة من من التسميد

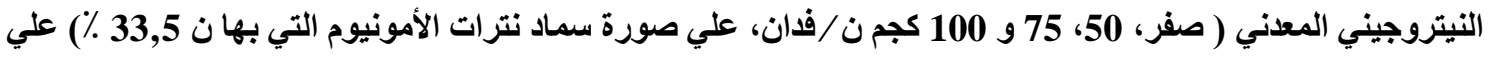

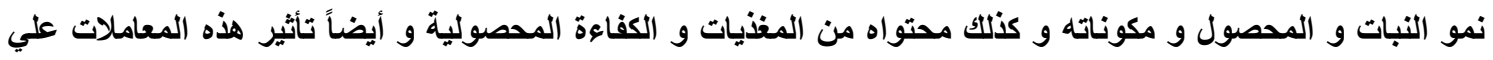

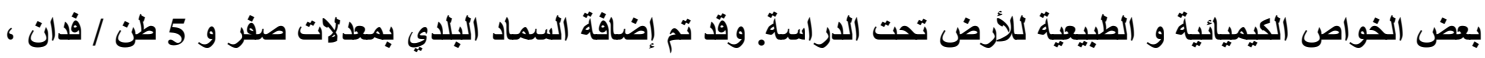

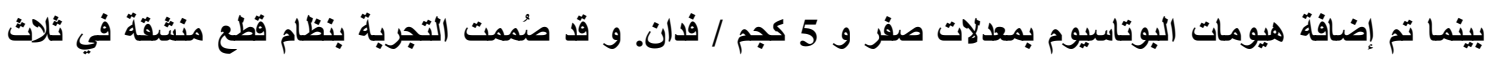
مكررات. - مكات و لقد أوضحت نتائج الاراسة وجود زيادة معنوية في جميع مقاييس النمو مثل طول النبات (سم) ، طول السنبلة (سم)،

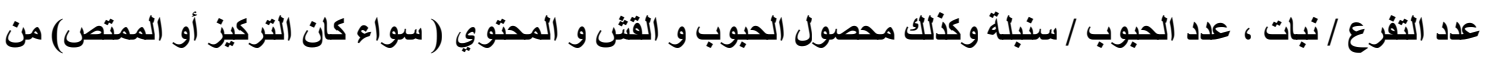

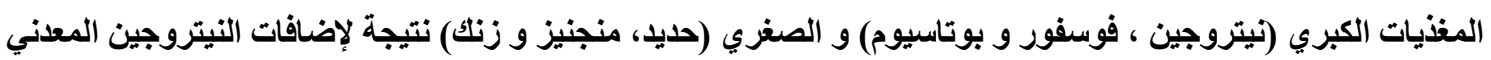

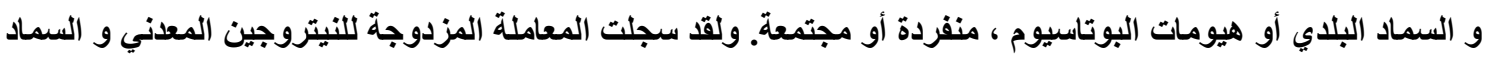

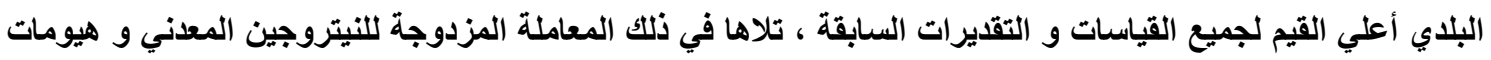

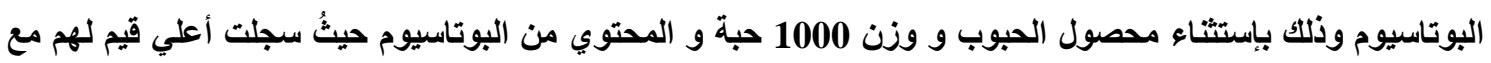

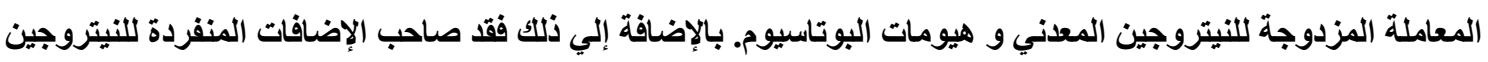

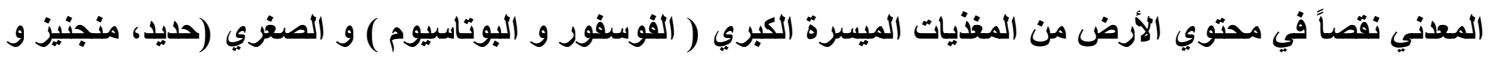

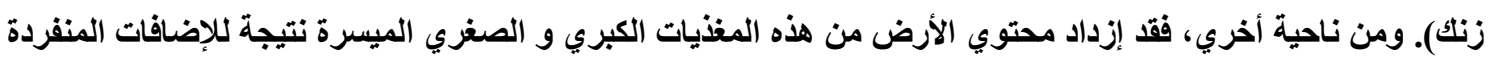

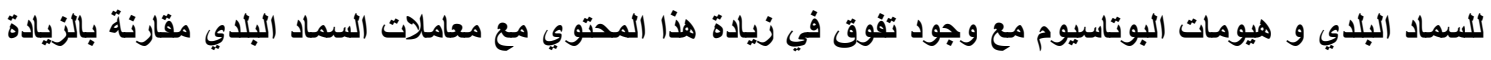

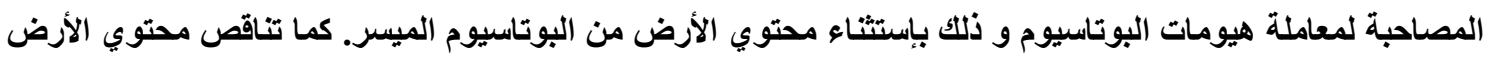

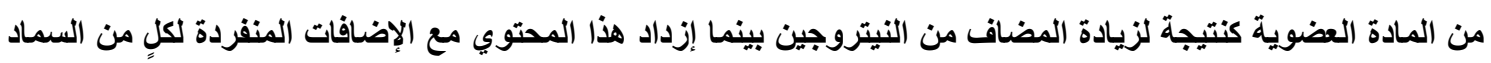

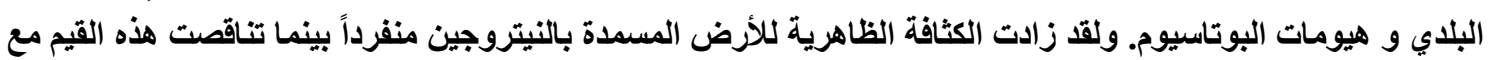

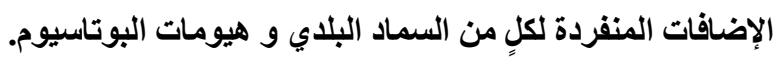

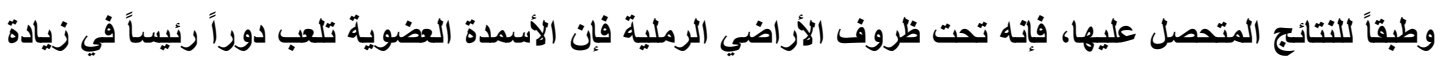

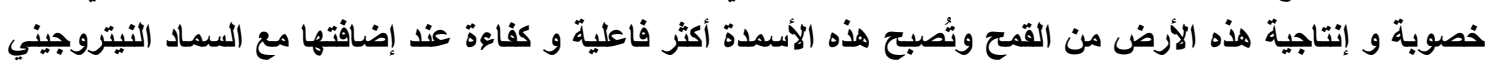


Improvement of sandy soil characteristics and its productivity of wheat ...............

أ.د/ بدر يوسف الكومى كلية الزراعة - جامعة المنوفية 